\title{
On Relative Translatability of Language with Special Reference to Contrastive Analysis between Chinese and English
}

\author{
Wei Wang \\ School of Interpreting and Translation, Beijing International Studies University, Beijing, China \\ Weihong Zhou \\ School of Foreign Languages, Ludong University, Yantai, China
}

\begin{abstract}
The issue of translatability has always been in dispute in translatology. On the one hand, languages are translatable, which can be demonstrated from different perspectives such as the general characteristics of language, the parallel linguistic structures, the cultural similarities, and the sameness of the intelligence quotient of all human races. On the other hand, there exist a series of limits in translation which obstruct the translatability of languages. Thus language can be described as relatively translatable. Translators are supposed to provide hybrid versions so as to facilitate communication and decrease tension between source language text and target language text.
\end{abstract}

Index Terms - translatability, translatology, translatable, language, linguistic structure, culture

\section{INTRODUCTION}

Translating is a complex and fascinating task. Due to semantic and formal barriers widely existing between natural languages, linguists and translators have not yet discovered a universally effective theory to explain and predict all translating processes. However, we assume that the translated version can at least be functionally equivalent to the ST (source language text).

By analyzing the theory of functional equivalence, it can be found that this theory proclaims that language is functionally translatable. Actually the question of translatability of language has always been in dispute among translation theorists and linguists. Due to the general characteristics of language, the parallel linguistic structures, the cultural similarities, and the sameness of the intelligence quotient (IQ) of all human races, language is translatable. On the other hand, there are various limits in translation that obstruct the translatability of language. As a result, translation seems impossible due to these limits. Consequently the translatability of language can only be described as relative instead of absolute.

This paper analyzes the question of translatability of language from various perspectives, namely, functional grammar, formal approach, cultural studies, psychology, and concludes that language is relatively translatable.

\section{TRAnSLATABILITY}

Thanks to the remarkable development of modern linguistics, cultural studies, psychology and some other natural sciences, translatology has been on the way towards a systemic and organized science. However, it is not mature enough. Correspondingly, the issue of translatability of language should be discussed from the perspectives of theoretical linguistics, cultural studies and psychology.

\section{A. Language as a System}

Ferdinand de Saussure (1983) defines the term language as a structured system. A language is a repository of sound patterns, and writing is their tangible form. A language as a structured form is both a self-contained whole and a principle of classification. This interpretation of language by Saussure shows that language is a systemic structure. Saussure further classifies language and speech. Speech is heterogeneous while language is homogeneous. Language is a means of verbal communication. Linguists start from different perspectives, but all of them maintain that language is a system.

\section{B. Linguistic Structure}

As language is a system, it should be composed by a series of structural elements. By comparing the linguistic elements of different languages, a translator may find that language is relatively translatable.

1. Linear character of linguistic signs

Various human languages may be different in many ways, but all of them must obey the rules of linearity, 
syntagmatic and paradigmatic relations. For example, either English or Chinese should follow these rules in order to be organized into a system, which is clearly demonstrated by Figure I. These characteristics make the translation between different languages possible.

Figure 1

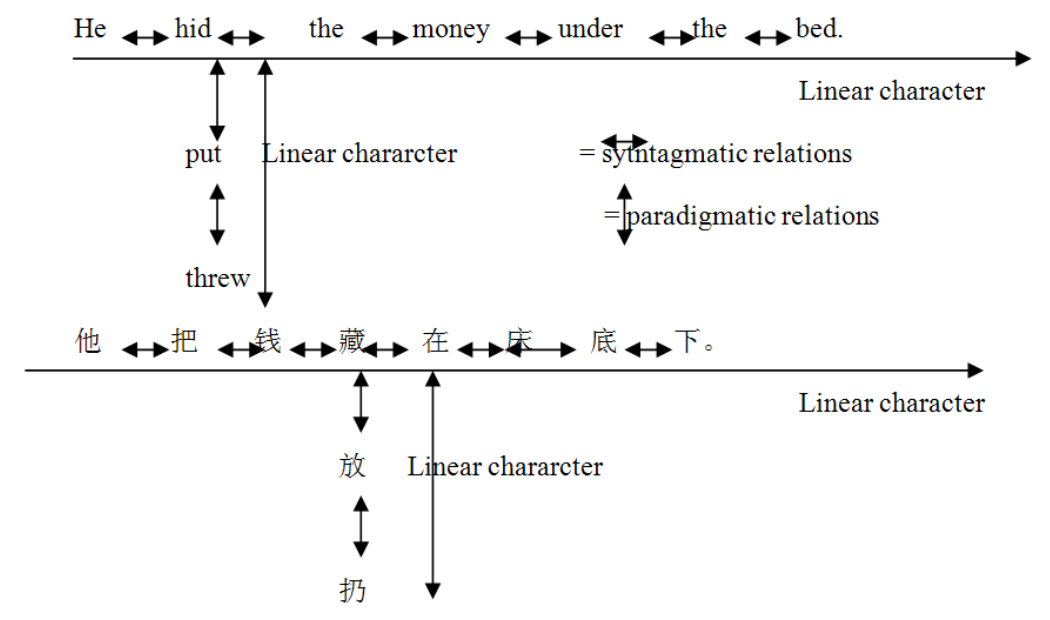

\section{Organization of linguistic structure}

The former analysis shows that language is a system. But in what way can this system be described and prescribed? Different linguists have made their contributions to this research. In Halliday's (1973) opinion, the semantic system is one the three strata, that constitute the linguistic system, which includes the semantic system (the meaning), lexicogrammatical system (the wording, i.e. syntax, morphology and lexis), phonological system (the sound). Secondly, he consumes that the semantic system consists of four functional components: experiential, logical, interpersonal and textual. Each component of the semantic system specifies its own structures, as the 'output' of the options in the network (so each act of choice contributes to the formation of the structure). The structure of linguistic system shows that each rank plays a specific function in the whole linguistic system. For example, various groups have different functions in the rank of clause. This point is shown in the following table.

\begin{tabular}{|l|l|l|l|}
\hline $\begin{array}{l}\text { Types of } \\
\text { group }\end{array}$ & $\begin{array}{l}\text { Nominal Group } \\
{[1] \text { He (他) }} \\
{[2] \text { his bill(他的帐单) }}\end{array}$ & $\begin{array}{l}\text { Verbal Group } \\
\text { paid(付) }\end{array}$ & $\begin{array}{l}\text { Adverbial Group } \\
\text { very carefully. } \\
\text { (小心翼翼地) }\end{array}$ \\
\cline { 2 - 5 } $\begin{array}{l}\text { Clause } \\
\text { Functions }\end{array}$ & \begin{tabular}{ll|l|} 
NG [1] \\
Subject
\end{tabular} \\
\hline
\end{tabular}

In order to demonstrate the functions of clause, the term transitivity is introduced into functional systemic grammar. In particular, it refers to a system for describing the whole clause, rather than just the verb and its object (Geoff Thompson 1996). First of all, transitivity is a semantic notion (at clause rank). Secondly, the transitivity serves to construe the world of experience into a manageable set of process types. Thirdly, a process consists of three components. It should be pointed out that Halliday's (1973) systemic and functional classification of language is not exclusive for the English language but is universal for all languages. Syntactic similarities between English and Chinese make the translating process possible.

In real communications speakers and receivers are often confronted with texts instead of isolated sentences or clauses. By analyzing two English versions of Luo Hua Sheng translated by Yang Xianyi (1998) and Yang Zijian (2000), we discover that there are several similarities and differences between ST, the TT1 and the TT2 (parts of the analysis are demonstrated in the following tables).

TABLE 2

\begin{tabular}{|l|l|l|}
\hline 母亲 & 说 & $\emptyset$ \\
\hline Sayer & Process:Verbal & Verbiage \\
\hline Subject & Predicator & Complement \\
\hline Mother & said & $\emptyset$ \\
\hline Sayer & Process:Verbal & Verbiage \\
\hline Subject & Finite/Predicator & Complement \\
\hline$\varnothing$ & said & Mother \\
\hline Verbiage & Process:Verbal & Sayer \\
\hline Complement & Finite/Predicator & Subject \\
\hline
\end{tabular}


TABLE 3

TABLE 3
\begin{tabular}{|l|l|l|l|}
\hline \multicolumn{2}{|l|}{ 让它荒芜着 } & 怪可惜 \\
\hline Carrier & Attribute \\
\hline Subject & 's & Complement & to let it waste \\
\hline It & a pity & to let it go wild \\
\hline It & would be & a pity & Carrier \\
\hline Carrier & Process: Relational & Attribute & Subject \\
\hline Subject & Finite/Predicator & Complement & \\
\hline
\end{tabular}

TABLE 4

\begin{tabular}{|l|l|l|l|l|}
\hline 既然 & 你们 & 那么 & 爱吃 & 花生 \\
\hline & Senser & & Process: Mental & Phenomenon \\
\hline Conjunctive adjunct & Subject & Adjunct & Predicator & Complement \\
\hline Since & you all & like to eat & peanuts & so very much \\
\hline & Senser & Process: Mental & Phenomenon & \\
\hline Conjunctive adjunct & Subject & Finite/Predicator & Complement & Adjunct \\
\hline
\end{tabular}

The major similarities are: (1) among the six major processes, five of them appear in the ST, the TT1 and the TT2. They are: existential process, verbal process, mental process, relational process (attributive and identifying), and material process. Each clause of the ST corresponds to the TT1 and TT2 in the process types, i.e. relational to relational, material to material, etc. (2) Both the ST and the TT1 and TT2 follow the same pattern of 'Subject+Predicator+Complement'. The syntactic structure of the SL and TL is almost the same. Similar viewpoint is also expressed in A History of Grammaticalization in Chinese - Motivation and Mechanisms of Evolution of Chinese Morpho-syntax written by Shi Yuzhi and Charles N. Li (2001). SVO pattern is the best and most economical optimal structure. The Proto-Indo-European follows the SOV pattern, but later it changes into SVO. Both English and Chinese follow the pattern of SVO. (3) Both the ST and TT1 and TT2 can be analyzed on the rank of clause. (4) The functions of the different elements of the clause such as subject, predicator and complement are the same. On the other hand, there are some differences between the ST and TT1 and TT2. (1) In the Chinese version there is no the element of finite but the TT1 and TT2 have this element. (2) The order of the pattern 'subject+predicator+complement' may be changed in the TT. For example, ‘母亲+说+ $\varnothing$ ' (subject+predicator+complement) is translated into ‘ $\varnothing$, said Mother' (complement finite/ predicator subject), which is also a common method of cohesion in English. But in Mandarin Chinese, the sentence pattern ‘ $\varnothing+$ 说 + 母亲' is wrong.

Both systemic functional grammar and generative grammar indicate that language is a well-organized system and there are universal principles hidden in the tremendous linguistic facts. Different languages can be translated due to the functional and structural similarities of each linguistic system. Therefore, it can be seen that language is translatable from the perspective linguistic universalities.

\section{Cultural Similarities and Translatability}

Although different nations have various cultures that obstruct their communication, cultural similarities overwhelm cultural differences. Among the numerous cultural facts on the earth, there is something universal and general to all human beings. Thanks to these cultural similarities, translation is possible. Influenced by Malinowski, Firth, Wang Li, and Luo Changpei, Halliday (1973) believes that "language is envisaged as: a form of behaviour potential, an open-ended set of options in behaviour that are available to the individual" (p. 48). While the context of situation is defined as the environment of any particular selection that is made from the total set of options accounted for in the context of culture. "The context often helps in understanding the particular meaning of the word, phrase, etc" (Jack C. Richards et al, 1992, 102). Thus a general description of these concepts can be formed. In a given cultural circumstance, people speak or write in order to communicate with each other. In this way different kinds of texts are created, e.g. narratives, drama, novel, poetry, dialogues, jokes, laws and so on. Each text is applied in its own circumstance, namely, context of situation. Accordingly the translator's work is to analyze the ST in its own cultural circumstance. The context of situation is a significant reference for him to make a proper translating strategy for the very text, which is the first stage in translating process. The main concern of the translator is the ST in a certain situational context instead of the specific words or sentences because of the fact that the ST in a certain situational context is the strategy-generating part. After obtaining the translating strategy, the translator ought to do the second stage's work, i.e., create the target-language text (TT) in its own cultural circumstance. Meanwhile, the context of situation of the TT should also be taken into consideration. The second stage requires the translator to deal with the basic information units, including words, groups, clauses and sentences. Text acts as the analyzing unit of translation while the clause is the basic transformational unit. Actually the so-called transformational unit is operational unit. The two stages are indispensable in translating process. The latter is conditioned by the former while simultaneously the ultimate aim of translation is realized by the latter.

Culture varies from one to another. But all races share common similarities of culture. For example, everyone has the tendency of adjusting himself or herself to the surrounding environment, of escaping danger, and of pursuing happiness. Every nation, either big or small, will organize its society. Each people will deal with the key stages in life such as birth, growth, marriage and death. In the process of development of civilization, different peoples have developed their rites, 
symbols etc. What's more, due to the advancement of modern technology, especially the information technology, the transmission of information has been dramatically accelerated. Thus, different cultures interact and become similar. For example, some English abbreviations have already entered modern Chinese such as CD, CIA, FBI, NASA, VOA, BBC, WTO, CNN, NATO, AIDS, SARS, DJ, DIY, DNA, RNA, ISBN, ICQ, MP3, MTV, MVP, NMD, TMD, IT, GPS, GDP, SOHO, UFO, GRE, ISDN, APEC, and PK, etc. These words repeatedly appear in the mass media in China and they have become part of Chinese. The following table explicitly shows the similarities between the English and Chinese proverbs.

TABLE 5
\begin{tabular}{|l|l|}
\hline English & Chinese \\
\hline eat the fruit of one's own doings & 自食其果 \\
\hline strike while the iron is hot & 趁热打铁 \\
\hline misfortunes never come singly & 祸不单行 \\
\hline castle in the air & 空中楼阁 \\
\hline at sixes and sevens & 乱七八糟 \\
\hline kill two birds with one stone & 一箭双雕 \\
\hline
\end{tabular}

This analysis clearly shows that cultural sameness makes translation possible. But he demonstrates this point from another perspective. One language-culture may emphasize the development and use of particular genres, e.g. epic poetry or animal folktales, which another language-culture may seldom employ and may even resolutely reject.

\section{Psychological Perspective}

According to the former functional and structural analysis of language, it can be concluded that the second point derived from the Sapir-Whorf hypothesis is wrong. This first point of it is still in dispute. The experiments on apes show that although they do not have language, they do have their own thought, which demonstrates that thought is prior to language. Another evident example is that people from different nations can communicate with the help of gestures and instruments despite the fact that they do not know each other's language. Therefore, it seems that the Sapir-Whorf hypothesis lacks convincing arguments.

Linguistic universals mean the common features that all human languages have. This is an innate faculty for language in general, not just for any particular language. Actually Chomsky's (2000) hypothesis of LAD can be used to explain the fact why people from different nations can communicate despite the fact that they do not know each other's language. It is because everyone is born with LAD, which is universal. There must be common experiences in the process of their language acquisition. Although their ways of thinking may have differences, peoples of this world do share some universal thinking patterns. For example, both Lao Tzu and Emerson ever talked about the topic of nature and believe human beings should live in harmony with Nature. They also hold the similar ideas of Tao and Universal Being. But their living period, cultural and situational contexts, languages are totally different. This case clearly demonstrates the viewpoint that peoples of this world do share some universal thinking patterns. As a result, translation between different languages is possible.

\section{THE LIMITS OF TRANSLATABILITY}

On the other hand, linguistic barriers (such as structural ambiguity), cultural differences, and stylistic features set series of obstacles in the translating process. Hence in some cases translators may encounter untranslatability.

\section{A. Linguistic Ambiguity and Situational Context}

Linguistic ambiguity is a universal phenomenon. Here is a sentence containing ambiguity: The police were ordered to stop drinking after midnight. According to different contexts of situation, it can be translated into four Chinese sentences: 1) 警察奉命于午夜起不得饮酒. 2) 警察奉命于午夜起禁止人们饮酒. 3) 午夜之后, 警察得到命令不得 饮酒. 4) 午夜之后, 警察得到命令禁止人们饮酒. The translator has to choose the appropriate TT according to the specific situational context. Catford's (1965) description of limits of translatability is scientific and acceptable. Sometimes a single word may have more than one meaning.

Secondly, translators may encounter different situational contexts. If the translator is asked to translate the simple sentence "Fire!" into Chinese, there will be several different translated versions according to the different contexts. 1) Situation 1: An employee is always late. So the manager of the company asks the president how to deal with the employee. The presidents says, “Fire!” According to this context, it can be translated into “(把他)解雇!” 2) Situation 2: A man in the street sees a building that is catching fire and he shouts, "Fire!" Then the sentence can be translated into “着火了!” 3) Situation 3: In a battlefield, a commander orders his soldiers by saying, "Fire!” Accordingly the sentence should be translated into “开火!"

\section{B. Cultural Barriers}

In addition, cultural factors and stylistic factors should not be ignored. Bao Huinan (2001) presents five major obstructions of translation caused by cultural differences: 1) zero equivalence; 2) conflict of word meaning; 3) semantic 
association; 4) pragmatic implication; 5) differences between peoples' psychology.

\section{Zero equivalence}

Zero equivalence means in the TL, there is no equivalent word to the word in the SL. For example, if a translator wants to translate this sentence “他只会马走日, 象走田,' perhaps he can only translates it into 'He only knows the basic moves of the Chinese chess.'

\section{Conflict of word meanings}

Sometimes the cultural information conveyed by the ST and the TT conflict. For example, the word 'dragon' means evil and brute in English. But in Chinese, '龙' is magical and powerful. Chinese people believe that they are the descendants of ‘龙'. As a result, 'dragon' and ‘龙' conflict.

\section{Semantic association}

Some words in the SL and TL have different associative meanings, which bring difficulty to the translator. For example, the Chinese word '狗'( $\operatorname{dog})$ sometimes has derogative meaning. But English and American people love dog and use the word as a commendatory term such as in the proverb 'love me love my dog', and in the sentence 'You are really a lucky dog!'

\section{Pragmatic implication}

Some fixed terms have specific meaning in a certain context of situation of the SL and TT. So sometimes word-for-word translation fails to convey the right meaning. For example, the word “剩女” is used to refer to single women in Chinese. If it were translated into "leftover women", target text readers may feel hard to understand its pragmatic implications.

\section{Differences of national psychology}

During the development of different nations, every nation has its own unique characteristics of national psychology. For example, there is Chinese proverb, ‘谋事在人, 成事在天.' Two TTs are available here. TT1 is like this, 'Man proposes, Heaven disposes.' TT2 is like this, 'Man proposes, God disposes.' Actually TT2 is more acceptable by the receptors because they believe Christianity. But TT1 conveys the original meaning of the ST because Chinese people believe that 'Heaven' is the most powerful entity in this world. But it's hard for the receptors to understand. Consequently the translator is often in a dilemma.

\section{Stylistic Factors}

Besides the factors presented above, due to stylistic differences, translation becomes even more complicated. The untranslatability of language is best displayed in translating poems. Some theorists maintain that poetry is untranslatable. Other styles such as advertisements have no fixed criteria of translation. It can be seen that there are no fixed rules for advertisement translation. Generally speaking, the technological style tends to obey a unified and strict set of rules. But as for the other styles such as novels, dramas, the translating rules and principles become more flexible and elastic.

\section{SOLUTION}

By reviewing the cases listed above, we find that translatability and untranslatability exist side by side in Chinese and English simultaneously (perhaps all natural languages). The translator shall try to overcome the conflict or tension between source language text and target language text by overcoming difficulties caused by untranslatability. The translated version is not always a mirror reflection of the original text. Instead, it is some kind of hybrid text consisting of both the content (from source language text) and linguistic norm (from target language text). In order to illustrate this viewpoint we present the Chinese-English translation of public signs used in Beijing International Studies University (see Table 6). 
TABLE 6

\begin{tabular}{|c|c|}
\hline 党委宣传部部长办公室 & Publicity Department, Director's Office (CPC BISU Committee) \\
\hline 党委宣传部办公室 & Publicity Department, General Office (CPC BISU Committee) \\
\hline 通识教育学院直属党支部书记办公室 & School of General Education, Party Branch Secretary's Office (CPC BISU Committee) \\
\hline 通识教育学院行政办公室 & School of General Education, Executive Office \\
\hline 通识教育学院教学管理办公室 & School of General Education, Office of Teaching Management \\
\hline 通识教育学院教工之家 & School of General Education, Faculty Club \\
\hline 二外广播电视台 & BISU TV Station \\
\hline 二外广播电视台演播室 & BISU TV Studio \\
\hline 演播室中控室 & BISU TV Studio, Central Control Room \\
\hline 校报编辑部 & BISU Gazette, Editorial Office \\
\hline 英文网站编辑部 & BISU English Website, Editorial Office \\
\hline 思想政治工作办公室 & Office of Ideological and Political Work \\
\hline 大学文化建设办公室 & Office of University Culture \\
\hline 网络宣传工作室 & Office of Internet Information \\
\hline 艺术教研室 & Teaching and Research Office of Arts \\
\hline 体育教学部 & Teaching and Research Office of Physical Education \\
\hline 计算机教研室 & Teaching and Research Office of Computer Science \\
\hline 数学教研室 & Teaching and Research Office of Mathematics \\
\hline 教师办公室 & Staff Office \\
\hline
\end{tabular}

In some samples listed above, Chinese and English versions form a kind of formal correspondence, e.g. 通识教育学 院院长办公室 (School of General Education, Dean's Office), 通识教育学院会议室 (School of General Education, Meeting Room), etc. As for phrases like大学文化建设办公室 and 网络宣传工作室, we propose that the English versions shall abide by the linguistic norm of English. Thus the two phrases are respectively translated into Office of University Culture and Office of Internet Information. 建设 (construction) and 宣传 (publicity) are omitted in the target language text. As for terms which are unique to Chinese context such as 党委宣传部部长办公室 and 党委宣传部 办公室, the standard name of the abbreviation word 党委 must be explicitly expressed in the target language text. Hence they are translated into Publicity Department, Director's Office, CPC BISU Committee and Publicity Department, General Office, CPC BISU Committee.

\section{CONCLUSION}

The above analysis shows that one the one hand, language is translatable which can be proved from the perspectives of the general characteristics of language, the parallel linguistic structures, the cultural similarities, and the sameness of the intelligence quotient of all human races. On the other hand, there are a series of limits which obstruct the translatability of language. In conclusion, language is relatively translatable instead of absolutely translatable or untranslatable. Translators are thus supposed to decrease the tension between source language text and target language text and realize the goal of communication. We expect further empirical studies shall focus on cultural differences, psychological differences as well as the application of artificial intelligence in translation.

\section{REFERENCES}

[1] Bao Huinan. (2001). Cultural Context and Translation. Beijing: China Translation Corporation.

[2] Catford, J. C. (1965). A Linguistic Theory of Translation. Oxford: Oxford University Press.

[3] Chomsky, Noam. (2000). New Horizons in the Study of Language and Mind. Cambridge: Cambridge University Press.

[4] Halliday, M.A.K (1973). Explorations in the Functions of Language. London: Edward Arnold.

[5] Richards, Jack C, John Platt \& Heidi Platt. (1992). Longman Dictionary of Language Teaching \& Applied Linguistics. London: Longman Group.

[6] Saussure, Ferdinand de. (1983). Course in General Linguistics. Tr. by Roy Harris. London: Gerald Duckworth \& Co. Ltd.

[7] Shi Yuzhi \& Charles N. Li. (2001). A History of Grammaticalization in Chinese. Beijing: Peking University Press.

[8] Thompson, Geoff. (1996). Introducing Functional Grammar. London: Edward Arnold.

[9] Yang Xianyi. (1998). A Retrospective of Chinese Literature (the Section of Modern Chinese Essays). Beijing: Foreign Language Teaching and Research Press.

[10] Yang Zijian. (2000). A Comparative Study between Chinese and English. Shanghai: Shanghai Foreign Language Education Press. 
Wei Wang was born in Dongying, China in 1979. He received PhD. degree in linguistics from Shanghai Jiao Tong University, China in 2008.

$\mathrm{He}$ is currently an associate professor in the School of Interpreting and Translation, Beijing International Studies University, Beijing, China. His research interests include translation studies and contrastive linguistics.

Weihong Zhou was born in Dezhou, China in 1978. She received M.A. degree in linguistics from Beijing International Studies University, China in 2004.

She is currently a lecturer in the School of Foreign Languages, Ludong University, Yantai, China. Her research interests include translation studies and applied linguistics. 